\title{
ECOLOGY OF A MEDICINAL TREE Strychnos ligustrina B1, IN DOMPU DISTRICT, WEST NUSA TENGGARA PROVINCE
}

\author{
Ogi Setiawan $^{1,2}$ and Budi Hadi Narendra ${ }^{1}$
}

\begin{abstract}
Strychnos ligustrina Blume is one of the important non timber forest products (NTFPs) for medicinal purposes in Dompu District. Its existence in the natural habitat has been threatened by exploitation of local people. Local people are interested in domesticating the plant, but cultivation technology has not been developed yet. Ecological information is needed to support and guide the development and management of the plant. This study aims to investigate the site characteristics, distribution pattern, stand density, dominance and its association with other species. Nine sample locations had been set up in forest area of the Dompu District. The transect survey was used to determine spatial distribution of S. ligustrina. The environmental variables were measured in each sample location. The line plot sampling method was used for inventory of vegetation. The result shows that the species was distributed in forest area with the altitude of up to $300 \mathrm{~m}$ above sea level. The whole range of S. ligustrina in Dompu District broadly experienced a dry climate with 5-6 of dry months and 1,032 $\mathrm{mm}$ of mean annual rainfall. S. ligustrina was able to grow on land that is physically strenuous and very varied soil properties. Stand density of S. ligustrina seedling and sapling were higher than that of pole and tree. Spatial distribution of the plant was clumped, and had a high positive association with Schoutenia ovata and Grewia koordersiana. S. ligustrina was not the most dominant species in its habitat, but conservation effort is needed because of its rarity.
\end{abstract}

Keywords: site characteristics, stand density, Important Value Index, distribution pattern, associated species

\section{INTRODUCTION}

Non-timber forest product (NTFPs) is one of important forest products other than timber. In tropical forest, NTFPs can be grouped into four categories : (1) fruits and seeds; (2) vegetative parts such as leaves, stems, barks and roots; (3) plant exudates such as latex and resin; and (4) small stems, poles and sticks (Peters, 1990; Grundy and Cambell, 1993; Cunningham, 1996; Ayuk et al., 1999; Dovie et al., 2002).

Medicinal plant is one of the prospective NTFPs in Indonesia which can be developed and

${ }^{1}$ Non Timber Forest Product Technology Research Institute, Jl. Dharma Bhakti No. 7, Ds. Langko, Kec. Lingsar, Lombok Barat, Nusa Tenggara barat, Indonesia

${ }^{2}$ Corresponding author : o.setiawan@forda-mof.org, o_setiawan @yahoo.com has a potential market. Not less than 400 ethnics in Indonesia have indigenous knowledge in the utilization of medicinal plant and have a strong relationship with forest in their daily life (Zuhud, 2003). In West Nusa Tenggara region, especially in Dompu District, a well known medicinal plant is Strychnos ligustrina Blume, known locally as songga or bidara laut. In 2004, production of S. ligustrina in Dompu District reached 6 tons (Dinas Kehutanan NTB, 2007).

Strychnos, as a genus of $S$. ligustrina, is a member of the Loganiaceae family and distributed throughout Asia, Australia, Africa and SouthAmerica (Heyne, 1987). The synonym of $S$. ligustrina is Strychnos lucida R.Br. S. ligustrina is a small deciduous tree up to $12 \mathrm{~m}$ tall, the bole often crooked and the diameter of up to $25 \mathrm{~cm}$, spiny when young, branches densely and finely 
lenticellate, grey and tendrils absent. Generally, the twigs are pale and marked by numerous paler, circular lenticels. Leaf blades are 2.6-6.1 x 1.7-3.7 $\mathrm{cm}$, much paler on the underside and always has 3distinct veined. Calyx is $1-1.2 \mathrm{~mm}$ long, corolla of 10-15 mm long and tube of 7-12 mm long, distinctly longer than the lobes. Stamens are inserted in the throat of the tube, filaments are short. Anthers are 1.2-1.8 mm long, and ovary of about $1 \mathrm{~mm}$ in diameter. Fruits globose with 2-2.5 $\mathrm{cm}$ in diameter, $2-3$ seeded. Seeds are nearly diskshaped, $12-15 \times 10-12 \times 2.5-5 \mathrm{~mm}$, densely short pubescent (Leenhouts, 1962).

Strychnos ligustrina, as medicinal plants, is frequently used in traditional medicine for some therapeutic applications such as depurative, stomachic, anthelmintic, boil, chancre, and antidote for snake poison (Subehan et al., 2006). The active ingredients in $S$. ligustrina are strychnine, loganin, brusin, tannin and steroid (Waluyo and Marlena, 1992; Itoh et al., 2006). Of the 190 Strychnos species, only seven, including $S$. ligustrina, contain strychnine. In Dompu District, local people use $S$. ligustrina to cure various diseases such as malaria, fever, skin disease, and blood circulatory disturbance. It can be used to stimulate nerve system, relieve soreness, and enhance appetite (Waluyo and Marlena, 1992; Sugiarso, 1992). The local people take stems, bark and fruits out of this tree.

Strychnos ligustrina has an important role in Dompu District. The stand still remains naturally, but its sustainability is seriously threatened by exploitation of local people for subsistent or commercial purposes. Like other medicinal plants in Indonesian forests, the availability of $S$. ligustrina is decreasing due to forest conversion and land degradation (Caniago and Siebert, 1998). Despite its potential for medicine, the tree has received little scientific attention and cultivation technology has not been developed yet. Local people have great interest in plantation of $S$. ligustrina to support local market demand and cater household need. Data are needed for guiding and supporting the development and management of $S$. ligustrina especially in determining cultivation technology. This study aimed to provide information on the ecology of S. ligustrina such as site characteristics, distribution pattern, stand density and basal area, Importance Value Index (IVI) and its association with other species.

\section{MATERIALS AND METHODS}

\section{A. Study Area}

The study was conducted in 2010 at Dompu District, West Nusa Tenggara Province. Based on the information from household industry that used S. ligustrina wood as raw material, the distribution of the tree was concentrated in forest area of five Sub Districts: Hu'u, Woja, Manggelewa, Kempo and Kilo. Nine sample locations was set up in these sub districts (Figure 1).

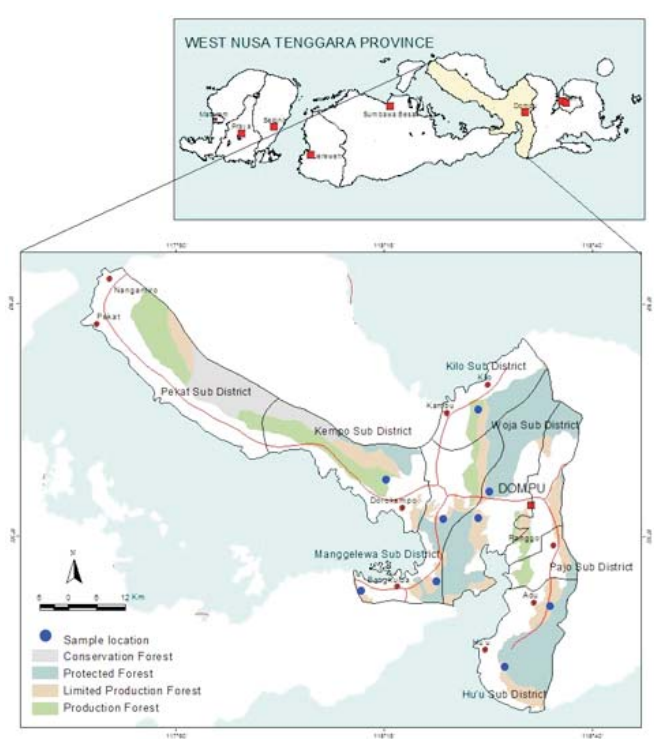

Figure 1. Study area of Dompu District and sample measurement locations 


\section{B. Spatial Distribution, Environment Variables and Soil Sampling}

In order to determine the spatial distribution of S. ligustrina, transects were set up in each sample location. All S. ligustrina were recorded and mapped by Global Positioning System (GPS). The environmental variables: altitude, slope, soil structure, surface stoniness percentage, rock outcrop percentage, air temperature and relative humidity, were measured in every sample location. Rainfall data for the study area were collected from the Meteorology, Climatology and Geophysical Agency (BMKG). The climate was classified using seven rainfall gauges (Dompu, Woja, Pajo, Kempo, Kilo, Manggelewa and Hu'u) (Schmidt and Fergusson, 1951). To determine soil characteristics, undisturbed and disturbed soil samples were taken at each sample location, and analyzed at the soil laboratory of the Balai Pengkajian Teknologi Pertanian (BPTP) West Nusa Tenggara. Total Nitrogen $(\mathrm{N})$ was measured using the standard Kjedahl procedure. Hydrometer procedure was used to determine the texture of the soil samples. Soil $\mathrm{pH}$ was measured with $\mathrm{pH}$-meter in a 1:5 soil water suspension. Available Phosphor (P) was determined using Bray method. $\mathrm{HCl} 25 \%$ extraction method was used to measure Potassium (K). Cation Exchange Capacity (CEC), organic carbon and exchangeable cations were determined by calorimetric method, spectrophotometer and flamefotometer respectively (Balai Penelitian Tanah, 2005).

\section{Vegetation Sampling}

The line plot sampling method (Simon, 2007) was used for vegetation inventory. In each sample location, measuring plots of $20 \mathrm{~m}$ x $20 \mathrm{~m}$ each were established along the line at $100 \mathrm{~m}$ intervals for tree stage (diameter at breast height $(\mathrm{dbh}) \geq 20 \mathrm{~cm})$. A total of 108 plots were set up in the study area. Pole stage (dbh 10-20 cm), sapling stage (dbh $<10$ $\mathrm{cm}$ and height $>1,5 \mathrm{~m}$ ) and seedling stage (height $<1,5 \mathrm{~m}$ ) were sampled respectively by using a 10 $\mathrm{m} \times 10 \mathrm{~m}$ quadrates, $5 \mathrm{~m} \times 5 \mathrm{~m}$ quadrates and $2 \mathrm{mx}$ $2 \mathrm{~m}$ sub-plots nested inside each plot. In each plot and sub-plot, all plant species were listed and measured its Dbh and height (Ferianita Fachrul, 2006). Plant specimens were collected and taken to Botanical Laboratory of Forest Conservation and Rehabilitation Research and Development
Center at Bogor. Plant specimens were identified by comparing them with the herbarium specimens and referring to other source.

\section{Data Analysis}

Means, standard deviation, minimum and maximum values, skewness coefficient and kurtosis coefficient were generated for each of the site characteristic variables, including: elevation, topography, climate, and soil properties. These values were analyzed descriptively. Stand density (stems/ha) of every growth stage (seedling, sapling, pole and tree) was calculated. The dbh were used to calculate basal areas $\left(\mathrm{m}^{2} / \mathrm{ha}\right)$ and frequency (probability of occurrence by plot) was also calculated based on the number of species in each plot. Basal area, density and frequency of each growth stage were converted into relative dominance, relative density and relative frequency. The IVI was sum of relative density (RD), relative dominance (RDom) and relative frequency (RF) (Roberts-Pichette and Gillespie, 1999). IVI was determined for all species found at study area including $S$. ligustrina. Distribution pattern of $S$. ligustrina in its habitat was calculated using Taylor method (Phillips, 1959). Contingency $2 \times 2$ table method was used to find out association between S. ligustrina and other species. Level of association for associated species was calculated using Jaccard index (Ludwig and Reynold, 1988).

\section{RESULTS AND DISCUSSION}

\section{A. Site Characteristics}

Strychnos ligustrina in Dompu District was generally found between 15 and $300 \mathrm{~m}$ above sea level. The highest elevation was recorded to appears in $300 \mathrm{~m}$ above sea level as it found in Manggelewa sub district. They grew mostly in the forest area near the beach. The distribution of $S$. ligustrina in relation to elevation is presented in Figure 2.

Precipitation data of seven rain gauges (from 1997 to 2008) in Dompu District indicated that the climate type of $S$. ligustrina habitat were dominated by E type (Schmidt and Ferguson, 1951). Some places such as Hu'u Sub District was D type, and Manggelewa and Pajo Sub Districts were classified as $\mathrm{F}$ type. Mean annual rainfall was $1,032 \mathrm{~mm}$, 


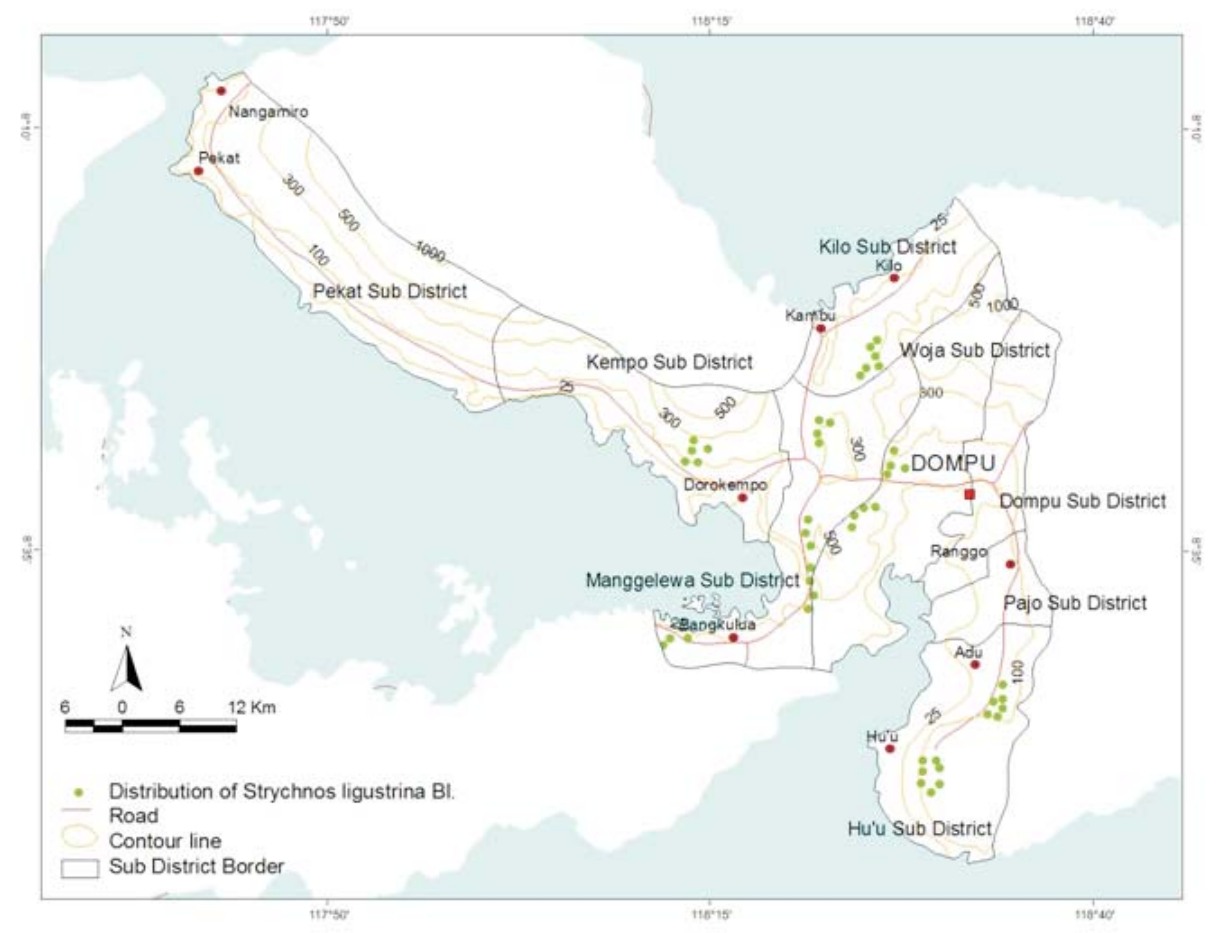

Figure 2. Spatial distribution of S. ligustrina in relation to elevation in Dompu District.

with the lowest in Manggelewa sub district and the highest in Pajo Sub District. The average dry month, $<60 \mathrm{~mm}$ rainfall, was from 5 to 6 months. The average air temperature was $30^{\circ} \mathrm{C}$ with the minimum of $27^{\circ} \mathrm{C}$ and the maximum of $33^{\circ} \mathrm{C}$. The average relative humidity, the minimum and the maximum value were $68 \%, 58 \%$ and $78 \%$, respectively.

In Dompu District, $S$. ligustrina can grow on land that is physically strenuous. Topographically, it was dominated by undulating hills with slopes ranging from gentle slope $(8 \%)$ to steep $(>45 \%)$. In general, surface stoniness ranged between $20 \%$ to $30 \%$, and rock outcrops between $15 \%$ to $50 \%$. The high amount of surface stoniness and rock outcrop indicated that serious erosion has happened. Qualitative observation showed the evidences of sheet, rill and gully erosion took place.

Strychnos ligustrina habitat was dominated by yellow-red podzolic soil and a small portion of regosol and cambisol (Nusa Tenggara Barat Soil Map, scale 1:250,000). Yellow-red podzolic soil profile formed at an advanced stage of weathering and leaching by the process of podzolization. It is similar in appearance and properties to a podzol but associated with the greater degree of chemical weathering and higher iron-oxide concentrations of a humid, tropical environment. Regosols are characterized by shallow, medium- to fine-texture, unconsolidated parent material that may be of alluvial origin and by the lack of a significant soil horizon (layer) formation because of dry or cold climatic conditions. Cambisols are characterized by the absence of a layer of accumulated clay, humus, soluble salts, or iron and aluminum oxides. They differ from unweathered parent material in their aggregate structure, colour, clay content, carbonate content, or other properties that give some evidence of soil-forming processes (Allaby, 2004).

Descriptive statistics of soil properties for the samples collected from nine sample locations are presented in Table 1. The soil texture varied from fine to moderate coarse and was predominated by sand fraction with a mean of $50.19 \%$. Granular and blocky were the most common soil structure at S. ligustrina habitat in Dompu District.

According to chemical soil properties (Pusat Penelitian Tanah, 2005), soil $\mathrm{pH}$ in S. ligustrina habitat ranged from slightly acid (5.5) to neutral (6.7). Under this condition the plants will ease in absorbting the nutrient; because the nutrient will dissolve easily in water at a neutral $\mathrm{pH}$ condition (Hardjowigeno, 2003). The distribution of soil pH was negatively skewed, indicating that there were 
Table 1. Descriptive statistic for the soil properties of S. ligustrina habitat in Dompu District $(\mathrm{n}=30)$

\begin{tabular}{|c|c|c|c|c|c|c|}
\hline Variable & Mean & Minimum & Maximum & $\begin{array}{l}\text { Standard } \\
\text { deviation }\end{array}$ & $\begin{array}{l}\text { Skewness } \\
\text { coefficient }\end{array}$ & $\begin{array}{c}\text { Kurtosis } \\
\text { coefficient }\end{array}$ \\
\hline $\mathrm{pH}$ & 6.3 & 5.5 & 6.7 & 0.3 & -1.14 & 0.91 \\
\hline N-Total $(\%)$ & 0.26 & 0.10 & 0.90 & 0.19 & 3.10 & 10.98 \\
\hline C-Organic $(\%)$ & 1.77 & 0.41 & 3.51 & 0.93 & 0.41 & -0.91 \\
\hline $\mathrm{P}(\mathrm{ppm})$ & 13.6 & 2.4 & 83.3 & 20.39 & 3.10 & 10.10 \\
\hline $\mathrm{K}(\mathrm{mg} / 100 \mathrm{~g})$ & 133.3 & 75.3 & 178.9 & 27.70 & -0.35 & -0.02 \\
\hline Sand $(\%)$ & 50.19 & 36.00 & 68.00 & 9.06 & 0.48 & 0.55 \\
\hline Silt $(\%)$ & 27.25 & 17.00 & 49.00 & 8.01 & 1.21 & 2.58 \\
\hline Clay $(\%)$ & 22.56 & 1.00 & 41.00 & 11.38 & -0.45 & -0.44 \\
\hline Cation Exchange Capacity (CEC) (\%) & 30.07 & 13.00 & 71.00 & 12.82 & 2.18 & 7.13 \\
\hline Exchangeable cations : - K (cmol/100g) & 1.94 & 1.10 & 3.29 & 0.64 & 0.37 & -0.49 \\
\hline - $\mathrm{Na}(\mathrm{cmol} / 100 \mathrm{~g})$ & 2.87 & 1.53 & 8.53 & 1.54 & 3.69 & 14.40 \\
\hline - $\mathrm{Ca}(\mathrm{cmol} / 100 \mathrm{~g})$ & 20.90 & 7.66 & 38.53 & 9.63 & 0.12 & -1.13 \\
\hline$-\mathrm{Mg}(\mathrm{cmol} / 100 \mathrm{~g})$ & 5.91 & 2.50 & 7.93 & 1.70 & -0.71 & -0.44 \\
\hline
\end{tabular}

some low values in the study area. Generally, the soils of the study area were low in organic carbon content. It ranged from 0.41 (very low) to $3.51 \%$ (high). The distribution of soil samples with respect to organic carbon content indicates a normal distribution. Since soil organic matter content is an indicator of available Nitrogen status of soils, it can be reported that the soils of $S$. ligustrina habitat were predominated by low of their available Nitrogen. It was indicated by the mean value of available Nitrogen $(0.26 \%)$. Nitrogen is responsible for growing healthy green leaf due to the formation of chlorophyll, the main unit for the production of carbohydrates, proteins and oxygen. Deficiency of Nitrogen in plants will show symptoms like stunted growth and pale green and yellow leaves. It can also lead to retarded root growth and resulting in the foliage turning yellow and pale green and increasing the plant's susceptibility to disease (Hardjowigeno, 2003).

Available Phosphorus in the study area varied from very low to very high. The minimum, maximum and mean values of available Phosphorus were 2.42, 83.31 and $13.62 \mathrm{mg} / 100 \mathrm{~g}$, respectively (Table 1). Cell development and good root growth are the Phosphorus responsibility. Plants that suffer from Phosphorus deficiency will have a poor root development and show symptoms like stunted growth (Hardjowigeno, 2003).
The available Potassium content of soils in $S$. ligustrina habitat was very high both for mean, minimum and maximum value. Potassium is responsible for chlorophyll formation which plays an important part in the strength of cell and encourages flower and fruit formation. Thus Potassium can enhance the ability of the plant to resist plant disease, insect attacks and cold condition as well the production and translocation of sugar in the plant. Plant with Potassium deficiency will look like weak stems. Other symptoms of Potassium deficiency include floppy older leaves with yellow tips and brown margins (Hardjowigeno, 2003).

In addition to soil cation, CEC of the study area ranged from moderate to very high, and exchangeable cations were generally very high. Of the exchangeable cations, $\mathrm{Na}$, was positively skewed in term of distribution, but the others $(\mathrm{K}$, $\mathrm{Ca}$ and $\mathrm{Mg}$ ) were normally distributed. CEC is the soil property that has strong relation with soil fertility. Soil with a high CEC is able to bind and provide nutrients better than low CEC soil.

\section{B. Stand Density and Basal Area}

Sixty eight species and twenty six families, including S.ligustrina, were recorded in 108 plots of nine sampling locations in Dompu District. The best represented families were Euphorbiaceae, Leguminosae and Apocynaceae. 
The average density of $S$. ligustrina for seedling, sapling, pole and tree stage were 2,935 stems/ha, 678 stems/ha, 51 stems/ha and 6 stems/ha, respectively (Table 2). High density at the stage of seedlings, saplings and poles or low density at the tree stage indicated two things: first, $S$. ligustrina in nature with a diameter equal to or more than $10 \mathrm{~cm}$ was declined due to the utilization by the local community, for subsistence and commercial purposes; and second, S. ligustrina is a shrubs type plant and plants with a diameter of more than 20 $\mathrm{cm}$ were rare. The average $\mathrm{dbh}$ for trees that can be used as raw material of household industry in Dompu District $(\mathrm{dbh}>10 \mathrm{~cm})$ was $17.1 \mathrm{~cm}$, ranging from 10 to $26 \mathrm{~cm}$. The range of free branch height was from 3 to $7 \mathrm{~m}$ with the average of $5.1 \mathrm{~m}$. The mean stand basal area of S. ligustrina (with $\mathrm{dbh}>10 \mathrm{~cm}$ ) was $2.9 \mathrm{~m}^{2} / \mathrm{ha}$.

\section{Importance Value Index}

The importance value index (IVI) of the total 68 species varied considerably for every growth stage. S.ligustrina was not the most important tree species in its habitat, but it was included in the top ten important species. Its IVI ranked second for seedling and sapling, third for pole and seventh for tree. The IVI of S. ligustrina were $42.5 \%, 41.2 \%$, $50.7 \%$ and $15.9 \%$ for seedling, sapling, pole and tree stage, respectively. The high IVI value of $S$. ligustrina was mostly determined by its high relative density and frequency although it had low relative dominance. Shoutenia ovata was the most important species for every growth stage. The IVI of top 10 tree species for every growth stage is presented in Table 2.

IVI value can be used as a parameter that reveals the ecological significance of species in a given ecosystem (Lamprecht, 1989). Species with high IVI are considered more important than those with low IVI. Prioritizing species for conservation can also use IVI as the parameter (Simon, 2002). Less priority for conservation is needed for species with high value of IVI, while species with low IVI need a high conservation effort. In our study, $S$. ligustrina was neither the highest nor the lowest species in term of IVI value, but it should be prioritized for conservation. Unwise harvesting by local people that threaten the existence of S. ligustrina was the reason.

Table 2. The Importance Value Index (IVI) of top 10 tree species for every growth stage in Dompu District.

\begin{tabular}{|c|c|c|c|c|c|}
\hline No & Species & RF $(\%)$ & RDom (\%) & $\mathrm{RD}(\%)$ & IVI $(\%)$ \\
\hline \multicolumn{6}{|c|}{ Seedling stage } \\
\hline 1 & Schoutenia ovata & 20.4 & 28.6 & 29.1 & 78.1 \\
\hline 2 & Strychnos ligustrina & 12.1 & 14.9 & 15.6 & 42.5 \\
\hline 3 & Ziziphus celtidifolia & 7.4 & 5.2 & 5.8 & 18.4 \\
\hline 4 & Grewia koordersiana & 6.5 & 6.2 & 4.4 & 17.1 \\
\hline 5 & Arytera littoralis & 3.4 & 5.7 & 5.3 & 14.4 \\
\hline 6 & Dracontomelon sp. & 4.0 & 3.8 & 4.8 & 12.6 \\
\hline 7 & Antidesma subcordatum & 3.1 & 3.3 & 3.1 & 9.5 \\
\hline 8 & Rawvolfia reflexa & 2.8 & 3.2 & 3.1 & 9.1 \\
\hline 9 & Pterospermum diversifolium & 4.0 & 2.2 & 2.4 & 8.6 \\
\hline 10 & Wrightia calycina & 2.8 & 2.1 & 1.7 & 6.6 \\
\hline \multicolumn{6}{|c|}{ Sapling stage } \\
\hline 1 & Schoutenia ovata & 13.8 & 18.2 & 16.4 & 48.4 \\
\hline 2 & Strychnos ligustrina & 15.0 & 6.2 & 20.1 & 41.2 \\
\hline 3 & Grewia koordersiana & 10.5 & 12.9 & 10.1 & 33.5 \\
\hline 4 & Dracontomelon sp. & 5.3 & 4.0 & 6.0 & 15.3 \\
\hline 5 & Crataeva nurvala & 6.1 & 4.1 & 4.3 & 14.4 \\
\hline 6 & Drypetes ovalis & 4.0 & 3.4 & 4.9 & 12.4 \\
\hline 7 & Ziriphus celtidifolia & 4.0 & 1.9 & 3.4 & 9.3 \\
\hline 8 & Jatropha sp. & 2.8 & 3.8 & 2.5 & 9.1 \\
\hline 9 & Xylopia sp. & 3.8 & 1.8 & 2.3 & 8.0 \\
\hline 10 & Arytera littoralis & 2.0 & 2.1 & 3.5 & 7.6 \\
\hline
\end{tabular}


Table 2. Continued.

\begin{tabular}{|c|c|c|c|c|c|}
\hline No & Species & $\mathrm{RF}(\%)$ & RDom (\%) & $\mathrm{RD}(\%)$ & IVI $(\%)$ \\
\hline \multicolumn{6}{|l|}{ Pole stage } \\
\hline 1 & Schoutenia ovata & 21.1 & 19.3 & 23.2 & 63.5 \\
\hline 2 & Grewia koordersiana & 18.9 & 15.7 & 18.1 & 52.7 \\
\hline 3 & Strychnos ligustrina & 20.0 & 9.5 & 21.2 & 50.7 \\
\hline 4 & Ziriphus celtidifolia & 8.6 & 5.9 & 8.1 & 22.7 \\
\hline 5 & Jatropha sp. & 5.4 & 3.4 & 4.2 & 13.0 \\
\hline 6 & Dysoxylum sp. & 2.7 & 1.7 & 1.9 & 6.4 \\
\hline 7 & Pterospermum diversifolium & 2.2 & 1.6 & 1.5 & 5.3 \\
\hline 8 & Crataeva nurvala & 1.6 & 1.6 & 1.5 & 4.8 \\
\hline 9 & Schleichera oleosa & 2.2 & 1.0 & 1.5 & 4.7 \\
\hline 10 & Kleinhovia bospita & 1.1 & 1.4 & 1.5 & 3.9 \\
\hline \multicolumn{6}{|l|}{ Tree stage } \\
\hline 1 & Schoutenia ovata & 14.0 & 10.7 & 16.6 & 41.3 \\
\hline 2 & Grewia koordersiana & 13.4 & 9.4 & 15.2 & 38.0 \\
\hline 3 & Crataeva nurvala & 10.5 & 14.0 & 12.0 & 36.5 \\
\hline 4 & Schleichera oleosa & 8.3 & 16.3 & 9.2 & 33.8 \\
\hline 5 & Tamarindus indica & 8.3 & 16.0 & 7.4 & 31.6 \\
\hline 6 & Ziziphus celtidifolia & 7.0 & 4.4 & 7.4 & 18.8 \\
\hline 7 & Strychnos ligustrina & 7.3 & 2.8 & 5.7 & 15.9 \\
\hline 8 & Diospyros aurea & 2.5 & 2.7 & 2.8 & 8.0 \\
\hline 9 & Gyrocarpus americanus & 3.2 & 2.5 & 2.3 & 8.0 \\
\hline 10 & Kleinhovia hospita & 1.9 & 1.6 & 2.5 & 6.1 \\
\hline
\end{tabular}

\section{Associated Species}

Plants that live naturally in its habitat will group themselves and find their own environment to fulfill its need. There is association and interaction among the member, and will create degree of integration (Resosoedarma, 1989). S. ligustrina in its habitat, associated with few species positively or negatively.

Strychnos ligustrina had positive association with Tamarindus indica, Schleichera oleosa, Schoutenia ovata,
Crataeva nurvala, Grewia koordersiana, and Ziziphus celtidifolia. The level of association varied, depending on Jaccard index value (Ludwig dan Reynold, 1988), closer to 1 indicates higher association level. Two species with the highest positive association with S. ligustrina were Schoutenia ovata and Grewia koordersiana. Positive association between species would create positive spatial relationship. It means if one species found in sampling, the existence probability of its pair is high (Barbour et al., 1999). Antidesma subcordatum, Ficus septica, Diospyros

Table 3. The association of S. ligustrina and others species in Dompu District.

\begin{tabular}{|l|l|r|r|r|}
\hline \multicolumn{1}{|c|}{ Species } & \multicolumn{1}{|c|}{ Associated species } & $\begin{array}{c}\text { Chi- } \\
\text { Square }\end{array}$ & $\begin{array}{c}\text { Association } \\
\text { type }\end{array}$ & Jaccard index \\
\hline \multirow{5}{*}{ S. ligustrina } & Schoutenia ovata & 4.75 & + & 0.78 \\
\cline { 2 - 5 } & Grewia koordersiana & 6.22 & + & 0.75 \\
\cline { 2 - 5 } & Crataeva nurvala & 5.25 & + & 0.54 \\
\cline { 2 - 5 } & Ziziphus celtidifolia & 4.68 & + & 0.52 \\
\cline { 2 - 5 } & Schleichera oleosa & 5.16 & + & 0.33 \\
\cline { 2 - 5 } & Tamarindus indica & 3.88 & + & 0.27 \\
\cline { 2 - 5 } & Pterospermum diversifolium & 12.65 & - & 0.12 \\
\cline { 2 - 5 } & Antidesma subcordatum & 5.17 & - & 0.11 \\
\cline { 2 - 5 } & Diospyros malabarica & 22.15 & - & 0.05 \\
\cline { 2 - 5 } & Kleinhovia hospita & 3.95 & - & 0.02 \\
\cline { 2 - 5 } & Ficus septica & & - \\
\hline
\end{tabular}


malabarica, Kleinhovia hospita and Pterospermum diversifolium had negative association with $S$. ligustrina and had a relatively low association level (Table 3).

In this study, $S$. ligustrina could associate either with high or low IVI value species. They showed tolerance to exist in the same space or interrelationship in sharing space for living. Mueller-Dombois and Ellenberg (1974) and Barbour et al. (1999) stated that every plant in the community would give space to grow to each other in the same area or habitat. Association of S.ligustrina and high IVI value species yielded positive association. Similarly, negative association would be created by association of S. ligustrina and species which had low IVI value.

\section{E. Distribution Pattern}

Vertically, S. ligustrina in Dompu District was not a dominant tree because its canopy only reached up to $15 \mathrm{~m}$. There were other species with $30 \mathrm{~m}$ canopy height. This indicates that $S$. ligustrina was a shade tolerant species. The distribution pattern of S. ligustrina horizontally was clumped where the presence probability of $S$. ligustrina at certain point will increase the existence of other $S$. ligustrina at another point in the vicinity. Clumped distribution can be influenced by some factors, such as differences in soil condition, resources, competition and natural plant reproduction pattern (Barbour et al., 1999). Naturaly, plants reproduce seeds which fall near its parent or vegetative regeneration around its parent.

\section{CONCLUSION}

Strychnos ligustrina was not the dominant species in its habitat, but an effort to conserve this species was needed because its sustainability is threatened by the local people. In Dompu District, $S$. ligustrina was found in the forest area with the altitude of up to $300 \mathrm{~m}$ above sea level. The whole range of S. ligustrina in Dompu District broadly is experienced a dry climate with 5-6 of dry months and 1,032 mm of mean annual rainfall. S. ligustrina was able to grow on land that is physically strenuous with various soil properties. Stand density of seedling and sapling were higher than pole and tree stage. Spatially, distribution of the plant was clumped, and has a high positive association with Schoutenia ovata and Grewia koordersiana.

\section{ACKNOWLEDGEMENT}

We would like to thank Mr. Mansyur and Ms. Lesi Tresnawati - members of research team, and staffs of Dinas Kehutanan Dompu for their assistance during field data collection.

\section{REFERENCES}

Allaby, M. 2004. A dictionary of ecology. Oxford University Press.

Ayuk, E.T., B. Duguma, S. Franzel, J. Kengue, M. Mollet, T. Tiki-Manga, and P. Zenkeng. 1999. Uses, management and economic potential of Irvingia gabonensis in the humid lowlands of Cameroon. Forest Ecology and Management 113: 19.

Balai Penelitian Tanah. 2005. Analisis kimia tanah, tanaman, air, dan pupuk. Petunjuk Teknis edisi I. Bogor.

Barbour, G.M., J.K. Busk, W.D. Pitts, F. S. Gilliam and M.W. Schwartz. 1999. Terrestrial plant ecology. $3^{\text {rd }}$ Edition. New York: The Benyamin/Cummings Publishing Company, Inc.

Caniago, I. and S.F. Siebert. 1998. Medicinal plant ecology, knowledge and conservation in Kalimantan, Indonesia. Economic Botany 52(3): 229-250

Cunningham, A.B. 1996. People, park and plant use : Recommendations for multiple-use zones and development alternatives around Bwindi Impenetrable National Park, Uganda. People and Plants Working Paper 4. UNESCO, Paris.

Dinas Kehutanan NTB. 2007. Statistik Dinas Kehutanan Provinsi NTB Tahun 2006. Mataram. NTB.

Dovie, D.B.K., C.M. Shackleton, and E.T.F. Witkowski. 2002. Direct-use values of woodland resources consumed and traded in a South African village. International 
Journal of Sustainable Development and World Ecology 9: 269283.

Ferianita Fachrul, M.F. 2006. Metode sampling bioekologi. Bumi Aksara. Jakarta.

Grundy, I.M., and B.M. Campbell. 1993. Potential production and utilization of oil from Trichilia spp. (Meliaceae). Economic Botany 47: 148153.

Hardjowigeno, S and Widiatmaka. 2007. Evaluasi kesesuaian lahan dan perencanaan tataguna lahan. Gadjah Mada University Press. Yogyakarta.

Hardjowigeno, S. 2003. Ilmu tanah. Medyatama Sarana Prakarsa. Jakarta.

Heyne, K. 1987. Tumbuhan berguna Indonesia Jilid III. Badan Litbang Kehutanan. Departemen Kehutanan. Jakarta.

Itoh, A., Y.Tanaka, N. Nagakura, T. Nishi and T. Tanahashi. 2006. A quinic acid ester from Strychnos lucida. J Nat Med 60: 146-148

Lamprecht, H. 1989. Silviculture in the tropics: Tropical forest ecosystems and their tree species-possibilities and methods for their long-term utilization. Eschborn, Germany.

Leenhouts, P.W. 1962. Loganiaceae in Steenis : Flora Malesiana Series I. Vol. 6. Rijksherbarium, Leyden, Holland.

Ludwig, J.A. and J.F. Reynold. 1988. Statistical ecology: A Premier on methods and computing. John Wiley and Sons New York.

Peters, C.M. 1990. Plenty of fruit but no free lunch. Garden 14: 813

Phillips, A.E. 1959. Methods of vegetations study. New York: Henry Holt and Company, Inc.

Resosoedarma, R.S, K. Kartawinata and A. Soegiarto. 1989. Pengantar ekologi. Bandung: CV Remaja Karya.
Roberts-Pichette, P. and L. Gillespie. 1999. Terrestrial vegetation biodiversity monitoring protocols. EMAN. Ocasional Paper Series, Report No: 9. Ecological Monitoring Coordinating Office, Barlington, Ontario.

Schmidt, F.H. and J.H.A. Fergusson. 1951. Rainfall types based on wet and dry period ratios for Indonesia with Western New Guinea. Djawatan Meteorologi dan Geofisik. Jakarta.

Simon, H. 2007. Metode inventore hutan. Cetakan I. Pustaka Pelajar Yogyakarta.

Simon, S. 2002. Inventory of woody species in Dindin Forest. Technical Report No. 01. IBCR/GTZ/FGRCP.

Subehan, T. Usia, H. Iwata, S. Kadota and Y. Tezuka. 2006. Mechanism-based inhibition of CYP3A4 and CYP2D6 by Indonesian medicinal plants. Journal of Ethnopharmacology 105: 449-455

Sugiarso, N.C. 1992. Profil aktifitas farmakologi dari kayu Bidara Laut. Seminar Pokjanas III. Ditjen POM. Jakarta. Page: 34.

Waluyo and Marlena. 1992. Identifikasi dan pemerikasaan paramater farmakognosi dari kayu Bidara Laut. Seminar Pokjanas III. Ditjen POM. Jakarta. Page: 25 .

Zuhud, A.M.E. 2003. Pengembangan tumbuhan obat berbasis konsep bioregional (Aplikasi azas keunikan sistem kedirian): Contoh kasus Taman Nasional Meru Betiri, di Jawa Timur. Makalah Individu Pengantar Falsafah Sains (PPS702) Pogram Pascasarjana / S3, Institut Pertanian Bogor . 